\title{
The cervical vertebrae of the Late Cretaceous abelisaurid dinosaur Carnotaurus sastrei
}

\author{
Ariel H. Méndez \\ Acta Palaeontologica Polonica 59 (3), 2014: 569-579 doi: http://dx.doi.org/10.4202/app.2012.0095
}

The cervical vertebral series of Carnotaurus sastrei from Argentina is described in detail, and compared with Majungasaurus crenatissimus from Madagascar, both Late Cretaceous (Maastrichtian) in age. Notable differences in the morphology of the cervical vertebrae, especially in the shape and development of the epipophysis and the neural spines, are observed between these two genera. These differences show a neck much more robust in Carnotaurus than in Majungasaurus, may be linked to the evolution of the clade in relation to the divergence time since the two genera shared a common ancestor, and functionally may relate to the feeding function associated to the extreme reduction of the forelimbs.

Key words: Dinosauria, Abelisauridae, Carnotaurus, Majungasaurus, neck, cervical vertebrae, morphology, Cretaceous, Argentina, Madagascar.

Ariel H. Méndez [arielhmendez@yahoo.com.ar], CONICET, Instituto de Investigaciones en Biodiversidad y Medioambiente, Quintral 1250, Bariloche, Argentina, and Museo Paleontológico Bariloche, Av. 12 de Octubre y Sarmiento, Bariloche, Argentina.

This is an open-access article distributed under the terms of the Creative Commons Attribution License (for details please see creativecommons.org), which permits unrestricted use, distribution, and reproduction in any medium, provided the original author and source are credited. 